\title{
EFFECT OF BIOACTIVE COMPOUNDS EXTRACTED FROM EUPHORBIOUS PLANTS ON HEMATOLOGICAL AND BIOCHEMICAL PARAMETERS OF Channa punctatus
}

\author{
Jaya SHAHI \& Ajay SINGH
}

\begin{abstract}
SUMMARY
Channa punctatus was exposed to four different concentrations of Rutin, Taraxerol and Apigenin. Changes in some hematological parameters of Channa punctatus were assessed to determine the influence of these compounds on test fish. Fish were exposed to sublethal concentrations ( $80 \%$ of $\mathrm{LC}_{50}$ of $24 \mathrm{~h}$ ) of these compounds for one week. Control fish were also administered for one week. Thereafter, blood samples were obtained from the control and experimental fish. Blood was assayed for selected hematological parameters (hematocrit, hemoglobin, red blood cell count, white blood cell count total plasma protein and plasma glucose concentration). The derived hematological indices of mean corpuscular hemoglobin concentration (MCHC), mean corpuscular hemoglobin (MCH) and mean corpuscular volume (MCV) were calculated. Sublethal concentrations of these compounds caused a dose dependent decrease in hemoglobin values coupled with a decrease in hematocrit values and red blood cell counts are an obvious indication of anemia. The total white blood cell counts and the differential white blood cell counts were decreased except for the lymphocytes, where there was a slight increase. Plasma protein and glucose were also lower in exposed fish when compared with control. The hematological indices $\mathrm{MCH}, \mathrm{MCHC}, \mathrm{MCV}$ were also lowered. The result from this study reveals high mortality rate and deleterious consequences on the health of fish subjected to acute exposure of Rutin, Taraxerol and Apigenin and therefore, should not be used directly in aquaculture without having the proper knowledge.
\end{abstract}

KEYWORDS: Channa punctatus; Rutin; Taraxerol; Apigenin; Toxicity; Hematology; Aquaculture.

\section{INTRODUCTION}

The intensive use of synthetic pesticides in agricultural fields and public health operation systems has resulted in serious environmental hazards ${ }^{36,38}$. With growing awareness of environmental pollution by pesticides, efforts are being made to find pesticides from plant origin ${ }^{4,26,35}$ because plants are virtually an inexhaustible source of structurally diverse and biologically active substances ${ }^{18}$. Several plants belonging to different families, which possess a number of compounds, such as saponins, tannins, alkaloids, alkenyl phenols, di- and triterpenoids etc. have

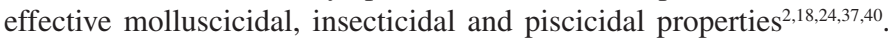
Active compound taraxerol and Apigenin extracted from Codium variegatum and Jatropha gossypifolia, respectively both belong to the family Euphorbiacea. Rutin was $\left(\mathrm{C}_{27} \mathrm{H}_{30} \mathrm{O}_{16}\right)$ (EC NO-205-814-1) purchased from the Sigma Chemical Company, USA. Hematological parameters were tested on freshwater fish Channa punctatus. This is an important fish of Indian fishing.

Despite the effectiveness of these compounds, knowing the mode of action and long-term effect of pesticides of plant origin on nontarget organism is necessary for their commercial usage. Hematological study is important in toxicological research because a hematological alteration is a good method for rapid evaluation of the chronic toxicities of a compound ${ }^{21}$. A thin epithelial membrane separates fish blood from the water and any unfavorable change in the water body is reflected in the blood ${ }^{21}$.

The deliberate introduction of these plant extracts in the aquatic ecosystem could therefore eventually lead to physiological stress in aquatic organisms. The physical and chemical changes in the aqueous environment often cause some physiological changes in fish, thus, the water quality of an aquatic body is highly crucial because it determines the productivity and other parameters necessary for fish survival. Environmental factors such as $\mathrm{pH}$, turbidity, alkalinity, dissolved oxygen and temperature influence the rate of reaction of pollutants entering the water or the lethal effects on the aquatic organisms ${ }^{12}$.

Many factors such as environmental and physiological are known to influence fish hematology; these include stress due to the catching, transportation, sampling, age and sex. The knowledge of hematological characteristics of the fish is important in determining its health status, toxicological and parasitological investigations as well as selecting 
SHAHI, J. \& SINGH, A. - Effect of bioactive compounds extracted from euphorbious plants on hematological and biochemical parameters of Channa punctatus. Rev. Inst. Med. Trop. Sao Paulo, 53(5): 259-63, 2011.

brooders for breeding purposes. The red blood cells count, hematocrit and hemoglobin concentration vary with diet and strain as well as temperature, season of the year and nutritional status of the fish ${ }^{5}$.

This study will report on the hematological changes in fish Channa punctatus, an important fish of Indian fishing, exposed to sub-lethal concentration of Taraxerol, Apigenin and Rutin.

\section{MATERIALS AND METHOD}

Collection of experimental animal: Channa punctatus (wt.29.21 \pm 1.83 gm; length $14.5 \pm 1.20 \mathrm{~cm}$ ) were collected from the Ramgarh Lake of Gorakhpur district of India. The collected fish were maintained in glass aquaria containing $100 \mathrm{~L}$ de-chlorinated tap water for acclimatization to laboratory conditions for one week. The water in aquaria was aerated continuously and changed daily. The fish were fed daily on commercial fish food. The dead animals were removed from the aquaria to avoid any contamination. The physiochemical properties of experimental water are: temperature-15 ${ }^{\circ} \mathrm{C}$, pH-6.80-7.05, Dissolved oxygen-6.5-7.2 mg/L, Free carbon dioxide-4.5-6.5 mg/L, Bicarbonate alkalinity-105-109 mg/L.

Extraction of Taraxerol from Codium variegatum: Pure taraxerol was isolated from the stem bark of $C$. variegatum by the method of CHATTERJEE \& BANERJEE ${ }^{8}$. The stem bark of $C$. variegatum was dried in an incubator at about $37{ }^{\circ} \mathrm{C}$ and powdered with the help of a mechanical device. From $2 \mathrm{~kg}$ of dried powdered stem bark, a concentrated solution of $C$. variegatum was extracted with petrol, for about 70 hours, in soxhlet apparatus. After evaporation of the solvent by vacuum pump, the isolated compound in dried form was obtained. Taraxerol is soluble in organic solvents such as $\mathrm{CHCl}_{3}$ and $\mathrm{CHCl}_{3}$ $\mathrm{MeOH}$. Identification of the Taraxerol $\left(\mathrm{C}_{32} \mathrm{H}_{48} \mathrm{O}_{9}\right)$ was confirmed from nuclear magnetic resonance (NMR) data of LEE et al. ${ }^{22}$.

Extraction of Apigenin from Jatropha gossypifolia: Pure apigenin was isolated from the leaf of Jatropha gossypifolia by the method of SUBRAMANIAN et al. ${ }^{41}$. Leaf of Jatropha gossypifolia were washed properly with the water and dried in an incubator at $37{ }^{\circ} \mathrm{C}$. The dried leaves were then powdered. About 50 grams of the leaf powder were subjected to extraction in Soxhlet apparatus with about 250-300 mL Ethyl alcohol for about 72 hours at $20-40{ }^{\circ} \mathrm{C}$. When extraction was completed, a small amount of crude yellow powder was obtained. After adding $\mathrm{NaOH}$ and $\mathrm{HCl}$, Apigenin was obtained which is crystallized by Methanol. Apigenin extracted from Jatropha gossypifolia leaf was confirmed by the UV spectral data of DORDEVIC et al. ${ }^{11}$.
Rutin was $\left(\mathrm{C}_{27} \mathrm{H}_{30} \mathrm{O}_{16}\right)(\mathrm{EC} \mathrm{NO}-205-814-1)$ purchased from the Sigma Chemical Company, USA.

Hematological experiments: A total of 40 healthy Channa punctatus were used for this study. The fish were acclimatized to laboratory conditions for a period of seven days. Ten fish were kept in glass aquaria containing 10 Ltrs dechlorinated water; three replicates were set up for this experiment. Fish were exposed to different sub-lethal doses $(80 \%$ of $\mathrm{LC}_{50}$ of $24 \mathrm{~h}$ ) SHAHI \& SINGH ${ }^{33}$, of Rutin, Taraxerol and Apigenin. Control groups are maintained separately. Artificial feeding was carried out. The water quality parameters of the water used in the test was determined by standard methods of $\mathrm{APHA}^{3}$.

The exposure period lasted for one week, after which blood samples were obtained from the control and experimental fish. Approximately $2 \mathrm{~mL}$ of blood was collected from the caudal peduncle using separate heparinized disposable syringes containing $0.5 \mathrm{mg}$ ethylene diamine tetra acetic acid (EDTA), an anticoagulant; it was properly mixed and used for hematological analysis. All hematological parameters such as hematocrit value, hemoglobin content, total leukocyte count, erythrocyte count and blood biochemistry such as serum glucose, serum protein, serum calcium and serum chloride was estimated by an auto analyzer $\operatorname{Sysmex}^{\mathrm{R}}$ fully computerized automatic blood cell counter (KX-21).

Results were expressed as mean \pm SE of three replicates and differences between means were considered to be significant when $p$ $<0.05$.

\section{RESULTS}

Hematological observation: The mean values for the hematological parameters of Channa punctatus were studied. The hematological parameters for the treated fish and those of the fish from the control tanks after one week showed significant difference. Rutin are highly toxic than taraxerol and apigenin. There was a significant increase in white blood cell count, lymphocyte increased and neutrophils decreased $(p<0.05)$ as compared to the control group (Table 1). Red blood cell counts exhibited a decrease in their numbers, mean corpuscular hemoglobin content (MCHC), mean corpuscular hemoglobin $(\mathrm{MCH})$ and mean corpuscular volume $(\mathrm{MCV})$ were significantly $(p<0.05)$ decreased than control groups. The hemoglobin and hematocrit values decreased significantly (Table 2). A significant decrease was observed in serum total protein, glucose, calcium and chloride in experimental groups when compared to control group (Table 3).

Table 1

Leukocyte and its differential counts of freshwater fish C. punctatus after one week exposure to sub-lethal doses of Rutin, Taraxerol and Apigenin

\begin{tabular}{ccccc}
\hline Parameters & Control & Rutin & Taraxerol & Apigenin \\
\hline & & Total Leukocyte Count & & \\
\hline WBC $\left(10^{3} \mathrm{~mm}^{3}\right)$ & $145.5 \pm 0.06$ & $189.7 \pm 0.09$ & $169.7 \pm 0.10$ & \\
\hline & & Differential Count & & \\
\hline Lymphocyte $(\%)$ & $86.7 \pm 0.03$ & $108.2 \pm 0.02$ & $98.8 \pm 0.13$ & $91.20 \pm 0.02$ \\
Neutrophils $(\%)$ & $13.3 \pm 0.24$ & $6.1 \pm 0.08$ & $8.9 \pm 0.06$ & $10.9 \pm 0.08$ \\
\hline
\end{tabular}

WBC- White blood cells; Significance at 0.05 level 
Table 2

Erythrocyte counts, hemoglobin content and hematocrit value of freshwater fish C. punctatus after one week exposure to sub-lethal doses of Rutin, Taraxerol and Apigenin

\begin{tabular}{ccccc}
\hline Parameters & Control & Rutin & Taraxerol & Apigenin \\
\hline Hematocrit $(\%)$ & $28.1 \pm 0.68$ & $17.2 \pm 0.02$ & $21.4 \pm 0.98$ & $25.1 \pm 0.13$ \\
Hemoglobin $\left(\mathrm{gdL}^{-1}\right)$ & $12.6 \pm 0.81$ & $7.34 \pm 0.09$ & $9.1 \pm 0.07$ & $10.2 \pm 0.06$ \\
\hline & & Erythrocyte Count & & \\
\hline RBC $\left(10^{6} \mathrm{~mm}^{3}\right)$ & $3.17 \pm 0.12$ & $1.92 \pm 0.06$ & $2.24 \pm 0.08$ & $3.67 \pm 0.13$ \\
MCHC $(\mathrm{g} / \mathrm{dL})$ & $34.9 \pm 0.37$ & $32.2 \pm 0.12$ & $31.8 \pm 0.08$ & $33.1 \pm 0.14$ \\
MCH $(\mathrm{Pg})$ & $57.4 \pm 0.02$ & $38.4 \pm 0.12$ & $39.7 \pm 0.05$ & $42.2 \pm 0.02$ \\
MCV $(\mu \mathrm{g})$ & $135.9 \pm 0.80$ & $115.8 \pm 0.02$ & $121.1 \pm 0.12$ & $128.4 \pm 0.06$ \\
\hline
\end{tabular}

RBC - Red blood cells; MCHC - Mean corpuscular haemoglobin concentration; MCH - Mean corpuscular hemoglobin (Pg); MCV - Mean cell volume; Significance at 0.05 level.

Table 3

Levels of non-cellular blood constituents of freshwater fish C. punctatus after one week exposure of sub-lethal doses of Rutin, Taraxerol and Apigenin

\begin{tabular}{lcccc}
\hline Parameter & Control & Rutin & Taraxerol & Apigenin \\
\hline Serum glucose $(\mathrm{mg} \%)$ & $67.4 \pm 0.32$ & $51.2 \pm 0.11$ & $64.9 \pm 0.80$ & $61.4 \pm 1.00$ \\
Serum protein $(\mathrm{gm} \%)$ & $4.97 \pm 1.22$ & $3.2 \pm 0.37$ & $4.1 \pm 0.32$ & $3.4 \pm 0.08$ \\
Serum calcium $(\mathrm{mg} \%)$ & $22.7 \pm 0.15$ & $10.3 \pm 0.18$ & $11.8 \pm 0.08$ & $15.3 \pm 0.16$ \\
Serum chloride (m.eq/L) & $137.4 \pm 0.18$ & $103.9 \pm 0.15$ & $112.6 \pm 0.12$ & $117.6 \pm 0.08$ \\
\hline
\end{tabular}

\section{DISCUSSION}

Mortality caused by all the compounds showed a significant positive correlation between dose and mortality. This may be due to an increase of extract concentration in water which resulted in more intakes of their active moieties in fish body. Data also showed a significant negative correlation between LC values and exposure periods. It could be due to several factors ${ }^{15}$ which may be acting separately or conjointly. Stability (life span) of active moieties in environment and their detoxification rate in animal body also alters the relationship of mortality and exposure periods $^{25,27}$.

According to BARTON ${ }^{6}$ stressors evoke non-specific responses in fish which enables the fish to cope with the disturbance and maintenance of its homeostatic state. If severe or long lasting, the response then becomes maladaptive and threatens the fish health and wellbeing. Therefore, in the presence of stressors (contaminants/pollutants), blood parameters and blood chemistry can be employed as a standard laboratory test to determine diseased conditions and metabolic disturbances in fish ${ }^{7}$. In the present investigation, it has been revealed that low level sublethal exposure of these compounds reduced hematological parameters. OMOREGIE et al..$^{29}$ reported that toxicants and pollutants have significant effects, which can result in several physiological dysfunctions in fish. Dysfunction in the fish induces changes in blood parameters.

In fish, a change of the blood cell distribution also has been correlated with the changes in environmental conditions ${ }^{10,14}$. The exposure of $C$. punctatus to sublethal concentrations of Rutin, Taraxerol and Apigenin caused a significant decrease in erythrocyte count, hemoglobin and hematocrit of the fish. The decrease in hemoglobin concentration is similar to those reported in C. gariepinus exposed to cassava effluents and tobacco (Nicotiana tobaccum) leaf extracts ${ }^{1,28}$. This pattern of response may be attributed to hemolysis which results in hemodilution, a means of diluting the hemoconcentration of the extracts thus reducing the effect of the toxicants/pollutant in its system ${ }^{32,39}$.

This effect on C. punctatus might have been achieved through failure or suppression of normal mechanisms promoting erythropoiesis and/or deficiency of some factors required for the maturation of the red cell. The causes of leucopenia observed in the present study are supposed to be according to the degeneration, depression, depletion and destruction of the blood forming materials by these compounds. The observed depletion in the hemoglobin and hematocrit values in the fish could also be attributed to the lysis of erythrocytes ${ }^{21}$. Thus, the significant reduction in these parameters is an indication of severe anemia. In the values obtained in the hematological indices, slight fluctuations were recorded in the MCV and MCHC but there was significant change in the $\mathrm{MCH}$, due to the reduction in cellular blood iron, resulting in reduced oxygen carrying capacity of blood and eventually stimulating erythropoiesis ${ }^{16}$.

The white blood cells in fish respond to various stressors including infections and chemical irritants 9 . Thus increasing or decreasing numbers of white blood cells are a normal reaction on the exposure of toxicants ${ }^{20}$. In the present investigation the increase in WBC (leukocytosis) may have resulted from the excitation of defense mechanism of the fish to counter the effect of the toxicant ${ }^{13}$. A sharp decrease was observed in percentage neutrophils, this was attributed to tissue damage. Finally, a slight but significant increase of lymphocyte was recorded in this investigation. 
SHAHI, J. \& SINGH, A. - Effect of bioactive compounds extracted from euphorbious plants on hematological and biochemical parameters of Channa punctatus. Rev. Inst. Med. Trop. Sao Paulo, 53(5): 259-63, 2011.

This is in agreement with the findings of SAMPATH et al..$^{32}$, when they exposed the Nile tilapia $O$. niloticus to a toxic environment.

Plasma protein were found to decrease, this could be attributed to renal excretion or impaired protein synthesis or due to liver disorder ${ }^{19}$. On the other hand, the observed decrease of plasma protein could also result from the breakdown of protein into amino acids first and possibly into nitrogen and other elementary molecule. Similar reduction in protein has also been reported by IBRAHIM et al. ${ }^{17}$ when brown Hisex chicks were fed Azadiracta indica ripe fruit. A change in plasma glucose was attributed to the changes in carbohydrate metabolism. Blood glucose has been employed as an indicator of environmental stress ${ }^{34}$.

It has been observed that plasma osmolarity and monovalent ion concentrations remain relatively constant for a variety of teleosts. It is generally recognized that sodium, chloride, potassium and calcium are primarily for osmoregulation in fish, either by exerting an osmotic effect (Sodium and Chloride) or by effective uptake and excretion (calcium and potassium). These elements also serve electrochemical, enzymatic and structural functions. Calcium serves a number of functions in fish. In bony fishes, it combines with phosphorus for the deposition of bone. It is possible that bone serves as a reservoir of calcium for plasma and tissues. Additionally, calcium appears to be important in reproduction ${ }^{30,31}$ and in mitochondrial function ${ }^{23}$.

The result from this study reveals deleterious consequences on the health of fish subjected to acute exposure of Rutin, Taraxerol and Apigenin and therefore, should not be used directly in aquaculture without having proper knowledge.

\section{RESUMO}

\section{Efeito de compostos bioativos extraídos de plantas eufórbicas sobre os parâmetros hematológicos e bioquímicos da Channa punctatus}

Channa punctatus foi exposta a quatro diferentes concentrações de Rutina, Taraxerol e Apigenina. Alterações de alguns parâmetros hematológicos da Channa punctatus foram acessados para determinar a influência destes compostos no peixe teste. Peixes foram expostos a concentrações sub-letais ( $80 \%$ Of LC50 em 24h) destes compostos por uma semana. Os peixes controles foram também expostos durante uma semana. A seguir, amostras de sangue foram obtidas do peixe controle e do experimental. O sangue foi estudado por parâmetros hematológicos selecionados (hematócrito, hemoglobina, contagem de células vermelhas e brancas, proteína plasmática total e concentração de glucose plasmática). Os índices hematológicos derivados da média da concentração corpuscular da hemoglobina (MCHC), a média de hemoglobina corpuscular $(\mathrm{MCH})$ e a média de volume corpuscular (MCV), foram calculados. Concentrações sub-letais destes compostos causaram decréscimo dose-dependente dos valores da hemoglobina unidos a decréscimo de valores de hematócrito e das contagens de células sanguíneas vermelhas o que caracteriza indicação óbvia de anemia. As contagens totais de células brancas e a contagem diferencial destas células estavam diminuídas exceto pelos linfócitos que mostraram leve aumento. A proteína plasmática e a glicose estavam também baixas nos peixes expostos quando comparados com o controle. Os índices hematológicos MCH, MCHC, MCV estavam também diminuídos.
Os resultados deste estudo revelam alto percentual de mortalidade e consequiências deletérias à saúde de peixes submetidos à exposição aguda de Rutina, Talaxerol e Apigenina e portanto eles não devem ser usados diretamente em aquacultura sem conhecimento apropriado.

\section{ACKNOWLEDGEMENTS}

One of the authors Jaya Shahi is thankful to University Grants Commission, New Delhi for financial Assistance.

\section{REFERENCES}

1. Adeyemo OK. Haematological and histopathological effects of cassava mill effluent in Clarias gariepinus. Afr J Biomed Res. 2005;8:179-83.

2. Alard FS, Geerts S, Triest L. Toxicité 'D' Ambrosia maritime L. plant molluscicides, sur less organism aquatiques non-cibles. Toxicon. 1991;29:745-50.

3. APHA. Standard methods for the examination of water and wastewater. New York: American Public Health Association; 1992. p. 1268

4. Arasta T, Bias VB, Thakur P. Effect of Nuvan on some biochemical parameters of Indian catfish Mystus vitatus. J Environ Res Sec A. 1996;80:80-3.

5. Barnhart RA. Effects of certain variables on the hematological characteristic of rainbow trout. Trans Amer Fish Soc. 1969;98:411-8.

6. Barton AB. Stress in fishes: a diversity of responses with particular reference to changes in circulating corticosteroids. Integr Comp Biol. 2002;42:517-25.

7. Celik ES. Blood chemistry (electrolytes, lipoproteins and enzymes) values of black scorpion fish (Scorpaena porcus) in the Dardanelles. Turkey J Biol Sci. 2004;4:716-9.

8. Chatterjee A, Banerjee A. Crotocaudin: a rearranged labdane type nordiditerpines from Croton caudatus geisel. Tetrahedran. 1977;33:2407-14.

9. Christensen GM, Faindt JT, Poeschi BA. Cells, proteins and certain physical-chemical properties of brook trout (Salvelinus fontinalis) blood. J Fish Biol. 1978;12:51-60.

10. De Wilde MA, Houston AH. Haematological aspects of the three moacclimatory process in the rainbowtrout, Salmo gaiirderi. J Fish Res Board Can. 1967;24:2267-81.

11. Dordevic S, Cakic M, Amr S. The extraction of apigenin and luteolin from the sage Salvia officinalis L. from Jordan. Sci J FACTA Universitatis.2000;1(5):87-93.

12. Fagbenro OA. Tilapia: fish for thought. $32^{\text {nd }}$ Inaugural Lecture. Akure, Nigeria: Federal University of Technology; 2002. 77p.

13. Gabriel UU, Obomanu FG, Edori OS. Haematology, plasma enzymes and organ indices of Clarias gariepinus after intramuscular injection with aqueous leaves extracts of Lepidagathis alopecuroides. Afr J Biochem Res. 2009;3:312-6.

14. Gardner GR, Yevich PP. Studies in the blood morphology of three estuarine Cypinodontiform fishes. J Fish Res Board Can. 1969;26:433-47.

15. Goodman LS, Gilman AG, Rall TW, Murad F. Goodman and Gilman's The pharmacological basis of Therapeutic. $7^{\text {th }}$ ed. New York: Macmillan Publishing Company; 1985

16. Hodson PV, Blunt BR, Spry DJ. Chronic toxicity of water-borne lead and dietary lead to rainbow trout (Salmo Gairdner) in lake Ontario water. Water Res. 1978;12: 869-78.

17. Ibrahim IA, Omer SA, Ibrahim FH, Khalid SA, Adam SE. Experimental Azadirachta indica toxicosis in chicks. Vet Hum Toxicol. 1992;34:221-4.

18. István U. Semi-natural products and related substances as alleged botanical pesticides. Pest Manag Sci. 2000;56:703-5. 

Paulo, 53(5): 259-63, 2011.

19. Kori-Siakpere O. Some alterations in haematological parameters in Clarias isheriensis (Sydenham) exposed to sublethal concentration of water-born lead. BioScience Res Commun. 1995;8:93-8.

20. Kori-Siakpere O, Ake JEG, Avworo UM. Sublethal effects of some selected haematological parameters of Heteroclarias (A hybrid of Heterobranchus bidorsalis and Clarias gariepinus). Int J Zool Res. 2006; 2:77-83.

21. Kori-Siakpere O, Ubogu EO. Sublethal hematological effects of zinc on the freshwater fish, Heteroclarias sp. (Osteichthyes: Clariidae). Afr J Biotechnol. 2008;7:2068-73.

22. Lee JH, Lee KT, Yang JH, Baek NI, Kim DK. Acetylcholinesterase inhibitors from the twigs of Vaccinium oldhami Miquel. Arch Pharm Res. 2004;27:53-6.

23. Lehninger AL. Biochemistry. $2^{\text {nd }}$ ed. New York: Worth Publishers; 1975. 1104p.

24. Marston A, Hostettmann K. Plant molluscicides. Phytochem. 1985;24:639-52.

25. Matsumura F. Toxicology of insecticides. $2^{\text {nd }}$ ed. New York: Plenum Press; 1985. p. 47 $74,78-80,163-165$ and 446

26. Mian LS, Mulla MS. Effects of pyrethroid insecticides on non target invertebrates in aquatic ecosystem. J Agric Entomol. 1992;9:73-98.

27. Mitra PK, Sud SC, Bagva HC. Acute toxicity of metasytox in buffalo calves. Indian J Exp Biol. 1978;16:813-5.

28. Omoniyi I, Agbon AO, Sodunke SA. Effect of lethal and sub-lethal concentrations of tobacco (Nicotiana tobaccum) leaf dust extract on weight and haematological changes in Clarias gariepinus (Burch.). J Appl Sci Environ Manag. 2002;6:37-41.

29. Omoregie E, Ufodike EBC, Keke IR. Tissue chemistry of Oreochromis niloticus exposed to sublethal concentration of Gammalian 20 and Actellic 25EC. J Aquat Sci. 1990;5:33-6.

30. Pang PKT, Kenny AD, Ogura G. Evolution of endocrinic control of calcium regulation. In: Pang PKT, Epple A, editors. Evolution of vertebrate endocrine system. Lubbock: Texas Tech Uni Press; 1980. p. 323-56.

31. Pang PKT, Yee JA. Evolution of endocrine control of vertebrate hypercalcimite regulation. In: Ishii S, Hirano T, Wada M, editors. Hormones, Adaptation \& Evolution. Tokyo: Japan Scientific Society Press; 1980. p. 103-111.
32. Sampath K, Velamnial S, Kennedy IJ, James R. Haematological changes and their recovery in Oreochromis massambicus as a function of exposure period and sublethal levels of Ekalus. Acta Hydrobiol. 1993;35:73-83.

33. Shahi J, Singh A. A comparative study on the piscicidal activity of synthetic pesticides and plant origin pesticides, to fish Channa punctatus. World J Zool. 2010;5:20-4.

34. Silbergeld EK. Blood glucose: a sensitive indicator of environmental stress in fish. Bull Environ Contam Toxicol. 1974;11:20-5

35. Singh A, Singh DK, Misra TN, Agarwal RA. Molluscicides of plant origin. Biol Agric Hortic. 1996;13:205-52.

36. Singh A, Singh SK, Yadav RP, Srivastava VK, Singh D, Tiwari S. Eco-friendly molluscicides, piscicides and insecticides from common plants. In: Livingston JV, editor. Trends in Agriculture and soil pollution research. New York: Nova Science; 2006. p. 205-230

37. Singh K, Singh A, Singh DK. The use of piperonyl butoxide and MGK-264 to improve the efficacy of plant-derived molluscicides. Pestic Sci. 1998;54:145-9.

38. Singh SK, Tripathi PK, Yadav RP, Singh D, Singh A. Toxicity of malathion and carbaryl pesticides: effects on some biochemical profiles of the freshwater fish Colisa fasciatus. Bull Environ Contam Toxicol. 2004;72:592-9.

39. Smit GL, Hattingh J, Burger AP. Haematological assessment of the effects of the anaesthetic MS 222 in natural and neutralized form in three freshwater fish species: interspecies differences. J Fish Biol. 1979;15:633-43.

40. Srivastava M, Srivastava VK, Singh A. Possibility of using different extracts of Lantana indica for control of mosquitoes and snail vectors. Nat Prod Radiance. 2007;6:122-6.

41. Subramanian SS, Nagarajan S, Sulochana N. Flavonoids of the leaves of Jatropha gossypifolia. Phytochemistry. 1971;10:1690.

Received: 10 November 2010

Accepted: 28 July 2011 


\section{LIBRARY OF THE SÃO PAULO INSTITUTE OF TROPICAL MEDICINE}

Website: www.imt.usp.br/portal

Address: Biblioteca do Instituto de Medicina Tropical de São Paulo da Universidade de São Paulo Av. Dr. Enéas de Carvalho Aguiar, 470. Prédio 1 - Andar térreo.

05403-000 São Paulo, SP, Brazil.

Telephone: 5511 3061-7003 - Fax: 5511 3062-2174

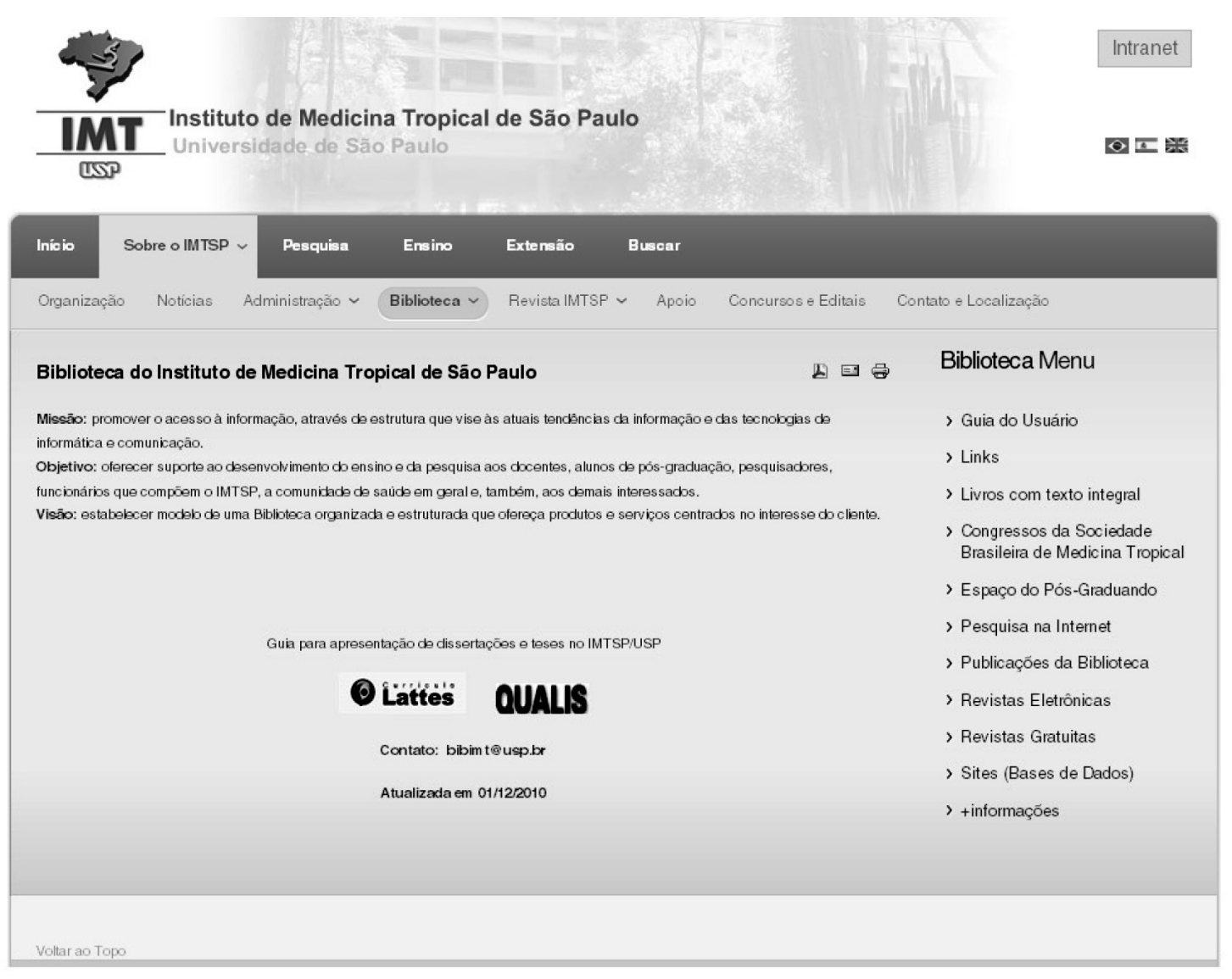

The Library of the São Paulo Institute of Tropical Medicine (IMTSP Library) was created on January 15,1959 in order to serve all those who are interested in tropical diseases. To reach this objective, we select and acquire by donation and / or exchange appropriate material to be used by researchers and we maintain interchange between Institutions thorough the Journal of the São Paulo Institute of Tropical Medicine, since the Library has no funds to build its own patrimony.

The IMTSP Library has a patrimony consisting of books, theses, annals of congresses, journals, and reference works.

The collection fo journals existing in the Library can be verified through the USP - Bibliographic Database - OPAC - DEDALUS http://dedalus.usp.br:4500/ALEPH/eng/USP/USP/DEDALUS/start of the USP network. 